\title{
Effects of Salinity on Some Haematological and Biochemical Parameters in Nile Tilapia, Oreochromus niloticus
}

\author{
Naglaa Elarabany ${ }^{1,}$, , Mohammed Bahnasawy ${ }^{1}$, Gamal Edrees ${ }^{2}$, Rajab Alkazagli ${ }^{1,3}$ \\ ${ }^{1}$ Zoology Department, Faculty of Science, Damietta University, Damietta, Egypt \\ ${ }^{2}$ Zoology Department, Faculty of Science, Mansoura University, Mansoura, Egypt \\ ${ }^{3}$ Zoology Department, Faculty of Science, Al-Asmariya University for Islamic Sciences, Zliten, Libya
}

Email address:

elarabny@gmail.com (N. Elarabany)

${ }^{*}$ Corresponding author

\section{To cite this article:}

Naglaa Elarabany, Mohammed Bahnasawy, Gamal Edrees, Rajab Alkazagli. Effects of Salinity on Some Haematological and Biochemical Parameters in Nile Tilapia, Oreochromus niloticus. Agriculture, Forestry and Fisheries. Vol. 6, No. 6, 2017, pp. 200-205. doi: $10.11648 /$ j.aff.20170606.13

Received: September 15, 2017; Accepted: September 26, 2017; Published: November 5, 2017

\begin{abstract}
Any change in haematological and biochemical parameters could be a predictor of unfavorable environment or effect of different stress factors. The present study was designed to assess different salinity concentration induced changes in some haematological and biochemical parameters in $64 \mathrm{O}$. niloticus fishes captured from Manzala Lake (Egypt), they were acclimatized and fed with commercial fish diet for one week before starting the experiment for another 2 weeks. Fishes were divided into 4 equal groups assigned as; control, $4 \mathrm{~g} \mathrm{NaCl} L \mathrm{~L}, 8 \mathrm{~g} \mathrm{NaCl} \backslash \mathrm{L}$ and $12 \mathrm{~g} \mathrm{NaCl} \mathrm{L}$. RBCs, HCT, Hb concentration, platelets count, superoxide dismutase activity, catalase activity, potassium level and serum total protein were estimated. The $\mathrm{HCT}, \mathrm{Hb}$ concentration, platelets count and potassium levels were significantly higher in $(4 \mathrm{gNaCl} \backslash \mathrm{L}, 8 \mathrm{gNaCl} \backslash \mathrm{L}$ and $12 \mathrm{gNaCl} \backslash \mathrm{L}$, respectively). The Superoxide dismutase activity (SOD), total protein, RBCs and catalase activit were significantly lower in $(4 \mathrm{gNaCl} \backslash \mathrm{L}, 8 \mathrm{~g} \mathrm{NaCl} \backslash \mathrm{L}$ and $12 \mathrm{gNaCl} \backslash \mathrm{L}$, respectively) compared to the control group. Other parameters such as WBCs, haematimetric indices (MCV, MCH, MCHC), malonedialdhyde (MDA) level, carbonyl protein (CP), glutathione reductase (GR) activity, as well as serum sodium, glucose, cortisol and IgM, did not show any significant differences in the estimated salinity concentrations.
\end{abstract}

Keywords: Tilapia, Salinity, Haematologic Parameters, Oxidative Stress Markers, Electrolytes

\section{Introduction}

Fish aquaculture is essential to enhance food security, in addition to give another source of income, especially in Egypt that has high population density [1,2].

It is outstanding that oceanic life forms, including fishes, are influenced by both inside (e.g. hormones and compounds) and outside components (e.g. their condition). Stress is any change in the physical or systemic elements that affect body health leading to disease or many causes death [3]. Moreover, it may cause disturbing homeostasis, stress reaction including many physiological changes including blood composition and immune mechanisms [4].
Fish response to any stressor could be achieved by many physiological changes to maintain homeostasis, osmolality and hematology $[5,6]$. Salinity is a main abiotic factor in aquaculture and its optimum degree are specific and may affect growth, and survival success [7]. There are variations in salinity tolerance among different species [8]. The physiological responses to high or low salinity levels in the aquatic environment have been studied in different fresh and marine species [9-11].

Nile Tilapia, Oreochromis niloticus is one member of Cichlidae family. It is the most common cultured freshwater species worldwide [12], although it could adapt to different levels of water salinities, it has the least salinity tolerance compared to other tilapia species [13]. Salinity usually affects 
the growth rate of euryhaline fishes because a part of the energy available for growth is consumed for osmoregulation $[14,15]$. The perfect salinity level is the one that insures higher growth rate and lowers energetic cost of osmoregulation.

Stress due to salinity changes has been reported to alter the standard haematological characteristic of teleosts, elevating plasma corticosteroids $[16,17]$ reducing the levels of some blood parameters and also increasing the values of some blood components. These changes can affect oxygen transport in the blood and across the gills.

Both haematological and biochemical parameters have been frequently used as an indicator of the general condition in different aquatic species [18-21]. Many studies were conducted to estimate the effects of the change in salinity levels on fish physiology [22, 23].

Due to the economic importance of $O$. niloticus in aquaculture in Egypt, the present study aimed to study the effects of different salinities on some haematological and biochemical measurements in $O$. niloticus.

\section{Materials and Methods}

\subsection{Fishes and Experimental Design}

Sixty-four $O$. niloticus (mean body weight $=112 \pm 14.5 \mathrm{~g}$ ) were obtained from Manzala Lake, Damietta, Egypt. Fishes, apparently healthy, were transported to the lab and acclimatized in dechlorinated water for one week and fed on a basal fish diet. After acclimation, the fishes were divided randomly into equal four groups with 8 fishes in all aquaria $(40 \times 35 \times 70 \mathrm{~cm})$ with capacity of $60 \mathrm{~L}$ water were used in the experiment, each group with different salinity level (Control, $4 \mathrm{~g} / 1,8 \mathrm{~g} / 1$ and $12 \mathrm{~g} / \mathrm{l}$ )for another 14 days.

The experimental salinity levels were obtained by adding 2 $\mathrm{g} / 1$ sodium chloride $(\mathrm{NaCl})$ gradually per day until $4 \mathrm{~g} / 1,8 \mathrm{~g} / 1$ and $12 \mathrm{~g} / \mathrm{l}$ were reached. Water salinity was measured daily to avoid any change. The experiment was done in natural photoperiod and the fishes were fed twice per day by $3 \%$ of the total stock biomass.

\subsection{Blood Sampling}

Fishes were fasted for 24 hours before sampling, blood was obtained from the caudal vein using $3 \mathrm{ml}$ syringe within less than 3 minutes to minimize handling stress. The collected blood was divided into two tubes, one containing heparin as anticoagulant agent for haematological assessment and the other was anticoagulant free for biochemical estimation.

Haematological measurements were assayed within one hour of sampling using blood cell automated counter, red blood cells count (RBCs), haematocrit (HCT)\%, haemoglobin content $(\mathrm{Hb})$, platelets count, and white blood cells count(WBCs)were evaluated. Different blood indices such as mean corpuscular volume (MCV), mean corpuscular haemoglobin $(\mathrm{MCH})$ and mean corpuscular haemoglobin concentration (MCHC) were calculated.

Anticoagulant free samples were used for serum preparation by centrifugation for 20 minutes at $1207 \mathrm{~g}$ within one hour of sampling, the sera samples were used for determination of malondialdehyde (MDA), protein carbonyl (PC), catalase (CAT), glutathione reductase (GR), sodium $\left(\mathrm{Na}^{+}\right)$, potassium $\left(\mathrm{K}^{+}\right)$, glucose $(\mathrm{GLU})$, total protein $(\mathrm{TP})$, cortisol and immunoglobulin $\mathrm{M}$ (IgM) while superoxide dismutase (SOD) was determined in RBCs lysate later on the same day with commercial kits. Absorbance values of samples and standards were measured using an UV spectrophotometer.

\subsection{Statistical Analysis}

Data were expressed as mean \pm SEM of different treated groups compared to control ones. Normal distribution of all parameters was tested. The results were analyzed using one way analysis of variance (ANOVA) followed by Tukey (HSD) test to compare groups with each other and Dennett two-sided test for comparisons with the control group. $P<0.05$ was considered significant. All statistical analyses were performed using XLSTAT program.

\section{Results}

Results tabulated in table 1, 2 showed a significant change in RBCs, haematocrit, haemoglobin, platelets count and potassium level. Haemoglobin content, RBCs and haematocrit were significantly lower $8 \mathrm{~g} / \mathrm{l}, 12 \mathrm{~g} / \mathrm{l}$ compared to control group. On the contrary, platelets count was significantly higher in the $8 \mathrm{~g} / \mathrm{l}, 12 \mathrm{~g} / 1$ groups with respect to the control group and that with salinity $4 \mathrm{~g} / 1$ (Table 1 ).

Table 1. Means \pm SEM of haematological parameters of Nile tilapia O. niloticus treated with different concentrations of salinities for 14 days.

\begin{tabular}{|c|c|c|c|c|c|}
\hline \multirow{2}{*}{ Parameter } & \multicolumn{4}{|c|}{ Salinity concentration } & \multirow{2}{*}{$\boldsymbol{P}$} \\
\hline & Control & $(4 \mathrm{~g} / \mathrm{L})$ & $(8 \mathrm{~g} / \mathrm{L})$ & $(12 \mathrm{~g} / \mathrm{L})$ & \\
\hline Erythrocytes $\left(10^{6} / \mu 1\right)$ & $1.89 \pm 0.13^{\mathrm{a}}$ & $2.02 \pm 0.08^{\mathrm{ab}}$ & $1.88 \pm 0.08^{\mathrm{ab}}$ & $1.83 \pm 0.14^{\mathrm{b}}$ & 0.046 \\
\hline $\operatorname{HCT}(\%)$ & $22.22 \pm 0.78^{\mathrm{ab}}$ & $24.28 \pm 0.85^{\mathrm{a}}$ & $19.56 \pm 0.91^{\mathrm{b}}$ & $19.53 \pm 0.88^{b}$ & $<0.01$ \\
\hline $\mathrm{Hb}(\mathrm{g} / \mathrm{dl})$ & $6.31 \pm 0.38^{\mathrm{ab}}$ & $7.01 \pm 0.22^{\mathrm{a}}$ & $5.69 \pm 0.27^{\mathrm{b}}$ & $5.78 \pm 0.30^{\mathrm{b}}$ & $<0.001$ \\
\hline platelets $\left(10^{3} / \mu \mathrm{l}\right)$ & $120 \pm 1.50^{\mathrm{a}}$ & $130.79 \pm 11.59^{\mathrm{a}}$ & $210 \pm 7.15^{\mathrm{b}}$ & $203 . \pm 8.28^{b}$ & $<0.0001$ \\
\hline Leucocytes $\left(10^{3} / \mu 1\right)$ & $4.760 \pm 2.22$ & $4.587 \pm 1.86$ & $4.116 \pm 2.19$ & $5.215 \pm 1.164$ & NS \\
\hline $\operatorname{MCV}(\mathrm{fl})$ & $117.5 \pm 7.45$ & $122.83 \pm 4.31$ & $106.21 \pm 3.23$ & $113.77 \pm 7.75$ & NS \\
\hline $\mathrm{MCHC}(\mathrm{g} / \mathrm{dl})$ & $28.4 \pm 1.36$ & $28.67 \pm 0.48$ & $28.81 \pm 0.36$ & $29.58 \pm 0.81$ & NS \\
\hline
\end{tabular}

Values are means \pm S.E.M. Values with different superscript letters within each row are significantly different (analysis of variance, $P<0.05$ ). 
On the other hand, superoxide dismutase activity, serum total protein and catalase activity were significantly lower in $(4 \mathrm{~g} / 1,8 \mathrm{~g} / 1$ and $12 \mathrm{~g} / \mathrm{l}$, respectively) compared to the control group. Other parameters such as MDA, PC and GR did not show any significant differences. The highest levels of GR were in the $4 \mathrm{~g} / 1$ group; while the highest levels of MDA and $\mathrm{PC}$ was found in that with salinity $12 \mathrm{~g} / \mathrm{l}$.
No significant differences were found also between different salinity treated group in sodium, glucose, cortisol, and $\operatorname{IgM}$. The highest levels of glucose and total protein were found in $4 \mathrm{~g} / 1$ group; levels of sodium and $\mathrm{IgM}$ were found in $12 \mathrm{~g} / 1$ group. Potassium concentration in all treated groups was significantly higher than the control group (Table 2).

Table 2. Means \pm SEM of biochemical parameters of Nile tilapia O. niloticus treated with different concentrations of salinities for 14 days.

\begin{tabular}{|c|c|c|c|c|c|}
\hline \multirow{2}{*}{ Parameter } & \multicolumn{4}{|l|}{ Salinity } & \multirow{2}{*}{$\boldsymbol{P}$} \\
\hline & Control & $(4 \mathrm{~g} / \mathrm{L})$ & $(8 \mathrm{~g} / \mathrm{L})$ & $(12 \mathrm{~g} / \mathrm{L})$ & \\
\hline $\operatorname{MDA}(\mathrm{nmol} / \mathrm{ml})$ & $29.06 \pm 5.67$ & $29.18 \pm 3.43$ & $33.72 \pm 4.93$ & $36.72 \pm 5.81$ & NS \\
\hline $\mathrm{PC}(\mathrm{nmol} / \mathrm{mg})$ & $301.73 \pm 20.27$ & $271.40 \pm 26.72$ & $293.60 \pm 36.46$ & $338.51 \pm 58.70$ & NS \\
\hline CAT (U/L) & $619.02 \pm 56.43^{\mathrm{a}}$ & $541.6 \pm 25.3^{\mathrm{ab}}$ & $614.36 \pm 42.48^{a}$ & $446 \pm 40.1^{\mathrm{b}}$ & $<0.001$ \\
\hline GR (U/L) & $38.18 \pm 4.43$ & $46.07 \pm 5.31$ & $34.94 \pm 5.21$ & $32.80 \pm 6.06$ & NS \\
\hline Sodium $(\mathrm{mEq} / \mathrm{L})$ & $150.40 \pm 1.34$ & $148.21 \pm 2.76$ & $147.79 \pm 1.46$ & $160.71 \pm 6.37$ & NS \\
\hline Glucose (mg/dl) & $72.88 \pm 2.98$ & $78.20 \pm 4.41$ & $67.8 \pm 6.48$ & $65.54 \pm 3.03$ & NS \\
\hline Serum total protein $(\mathrm{g} / \mathrm{dl})$ & $6.85 \pm 0.14^{\mathrm{a}}$ & $6.57 \pm 0.22^{\mathrm{a}}$ & $5.97 \pm 0.20^{\mathrm{b}}$ & $6.40 \pm 0.32^{\mathrm{a}}$ & 0.043 \\
\hline Cortisol (ng/ml) & $194.15 \pm 41.21$ & $163.70 \pm 23.71$ & $183.73 \pm 22.48$ & $159.26 \pm 24.48$ & NS \\
\hline $\operatorname{IgM}(\mathrm{mg} / \mathrm{dl})$ & $193.46 \pm 14.71$ & $189.06 \pm 10.61$ & $206 \pm 24.82$ & $232.08 \pm 31.00$ & NS \\
\hline
\end{tabular}

Values are means \pm S.E.M. Values with different superscript letters within each row are significantly different (analysis of variance, $\mathrm{P}<0.05$ ).

\section{Discussion}

Tilapia culture needs more precise information on stress effect and control to ensure fish good health conditions, particularly those introduced to a new environment. Haematological parameters can be good indicators of the physiological condition for fish farmers, which are crucial to prevent and control of stress-induced pathologies due to environmental changes [24].

The current study results showed a significant effect of different salinity levels on some estimated parameters. The results revealed a decrease in both haemoglobin content, RBCs and haematocrit in $8 \mathrm{~g} / 1$ and $12 \mathrm{~g} / 1$ treated groups, These findings are in agreement with other researcher who found a significant effect of salinity on RBCs, HCT and $\mathrm{Hb}$ in different species, this result may be associated with osmoregulatory dysfunction induced by high salinity levels [25-27]. Low haematocrit percentages in fishes under stress could be explained by reduced volume of RBCs due to osmotic changes caused by ion leakage from the plasma [28]; while no significant differences were found in $\mathrm{MCV}, \mathrm{MCH}$ and MCHC values in treated groups, these results are in according with the findings of previous results [27, 29, 30].

White blood cells count in fishes is a good indicator of physiological stress [31]. The current study results showed an increase in the leucocytes count in the highest salinity treatment $(12 \mathrm{~g} / \mathrm{l})$, similar results were found in rainbow trout, Oncorhynchus mykiss, placed in high salinity levels showed increased leucocytes count compared to those placed in fresh water [32], and silver barb, Barbonymus gonionotus, when placed in brackish water [33]. This elevation may result from the interaction of prolactin and cortisol in a non-specific immune response [27].

Although WBCs are the main immune cells, in fishes, thrombocytes have the capability to play a role immune response by producing and releasing a wide array of bioactive proteins [34] and their ability of phagocytosis [35].

Platelets count in the $8 \mathrm{~g} / 1$ and $12 \mathrm{~g} / 1$ groups increased significantly compared to control and $4 \mathrm{~g} / \mathrm{l}$ group. Elevation in platelets count may indicate a non-specific immune response due to stress induced by high salinity [32, 33]. These results are in agreement with the significant increase in thrombocytes due to increased salinity levels in Tilapia guineensis [30].

Superoxide dismutase activity and catalase activity play an important role to protect cells against $\mathrm{H}_{2} \mathrm{O}_{2}$ production, [36]. In the current study, SOD and CAT activity were significantly lower in $(4 \mathrm{~g} / 1$ and $12 \mathrm{~g} / 1$, respectively) compared to the control group. Similar results were found in Acipenser naccarii where SOD and CAT activities were higher in $(12 \mathrm{~g} / 1$ and $8 \mathrm{~g} / \mathrm{l}$, respectively) compared to the other groups [37]. Increased SOD activity appears to be an adaptive response to increased generation of the superoxide anion [38]. Where catalase activity decreased in Apostichopus japonicas when exposed to $20 \%$ salinity for 72 hours. Moreover, $10 \mathrm{ppm}$ salinity induced elevation in catalase activity in Dicentrarchus labrax [11].

It was documented that stress usually causes imbalance in hydromineral [39]. Moreover, electrolytes are a good indicator of osmoregulation problems [40]. In the current study, the highest sodium level was found in the highest salinity treatments. This result is may be to effects increase salinity on renal tissue according findings [41]. The present study showed that serum $\mathrm{K}^{+}$concentrations had a positive relation to salinity level as it increased with increasing salinity, the same pattern was found in $O$ niloticus, by Karsi and Yildiz (2005), where plasma $\mathrm{K}^{+}$increased significantly following direct transfer from fresh water to different 
salinities. Moreover, did not find any significant change in both serum sodium and potassium levels associated with different salinity levels [26, 42].

Glucose concentration is maintained within very narrow limits, regulated by hormonal control, even in fasting state, because glucose is the main source of energy for the central nervous system. Glucose concentration in groups $8 \mathrm{~g} / 1$ and $12 \mathrm{~g} / 1$ decreased by increasing salinity; while increased in group $4 \mathrm{~g} / \mathrm{l}$ compared to the control group, this result may be due to the high rate of glycogenolysis to meet high energy requirements to overcome stress [43, 44]. Moreover, Fishes live in high salinities level could be consuming more amounts of glucose to cover the higher energy demands of different osmoregulatory organs as observed in other euryhaline fish species $[45,46]$.

Total protein is also thought to be related to a stronger innate immune response in fish [47]. In the present study, total protein was significantly lower in $8 \mathrm{~g} / 1$ group compared to the control group. This decrease in plasma proteins with an increment of salinities may be the high osmoregulatory vitality request. This result is in agreement with other studies where protein levels were significant decline with increased salinity $[48,49]$.

Cortisol is well known to suppress fish immune functions in relation to various stresses [50]. In the present study, the highest level of cortisol was found in the $8 \mathrm{~g} / 1$ group; while its lowest concentration was detected in the $12 \mathrm{~g} / 1$ group. The increase of plasma cortisol value is considered to be a primary indicator of stress response [51]. Similar results were found in tambaqui, (Colossoma macropomun), where higher salinity levels caused an increase in cortisol level [52], Moreover, in tongue sole (Cynoglossus semilaevis), cortisol levels were low in moderate salinity levels [53].

$\operatorname{IgM}$ is the main class of antibody molecules and has been previously detected in fish mucus [54]. In the present study, IgM was highest in the $12 \mathrm{~g} / \mathrm{l}$ group, this result might be explained by the effects increase salinity on $\operatorname{IgM}$, the similar increment was found when tilapia (O. mossambicus) was transferred from fresh water to seawater [17].

\section{Conclusion}

In conclusion, the present study showed that change in salinity concentration leads to stress that of the metabolic, biochemical as well as hematologic parameters in order to adapt the environmental changes to overcome oxidative stress.

\section{References}

[1] Macfadyen G, Nasr-Alla AM, Al - Kenawy D, Fathi M, Hebicha H, Diab AM, et al. Value-chain analysis-An assessment methodology to estimate Egyptian aquaculture sector performance. Aquaculture 2012; 362:18-27.

[2] de Azevedo RV, de Oliveira KF, Flores-Lopes F, TeixeiraLanna EA, Takishita SS, Tavares-Braga LG. Responses of Nile tilapia to different levels of water salinity/Respuestas de la tilapia del Nilo a diferentes niveles de salinidad del agua. Latin American Journal of Aquatic Research 2015; 43:828.

[3] Schulte PM. What is environmental stress? Insights from fish living in a variable environment. Journal of Experimental Biology 2014; 217:23-34.

[4] Hamid SA, Ahmed FM, Mohammed IA, Ali SM. Physical \& Chemical Characteristics of Blood of two Fish Species )Oreochromis niloticus and Clarias lazera). World's Veterinary Journal 2013; 3:17-20.

[5] Carragher JF, Rees CM. Primary and secondary stress responses in golden perch, Macquaria ambigua. Comparative Biochemistry and Physiology Part A: Physiology 1994; 107.56-49:

[6] McDonald G, Milligan L. Ionic, osmotic and acid-base regulation in stress. Fish stress and health in aquaculture 1997; 62:119-145.

[7] Ruscoe IM, Shelley CC, Williams GR. The combined effects of temperature and salinity on growth and survival of juvenile mud crabs (Scylla serrata Forskål). Aquaculture 2004; 238:239-247.

[8] Larsen PF, Nielsen EE, Meier K, Olsvik PA, Hansen MM, Loeschcke V. Differences in salinity tolerance and gene expression between two populations of Atlantic cod (Gadus morhua (in response to salinity stress. Biochemical genetics 2012;50:454-466.

[9] Hasenbein M, Komoroske LM, Connon RE, Geist J, Fangue NA. Turbidity and salinity affect feeding performance and physiological stress in the endangered delta smelt. Integrative and comparative biology 2013;53:620-634.

[10] Kültz D. Physiological mechanisms used by fish to cope with salinity stress. Journal of Experimental Biology 2015; 218:1907-1914.

[11] Sinha AK, AbdElgawad H, Zinta G, Dasan AF, Rasoloniriana $\mathrm{R}$, Asard $\mathrm{H}$, et al. Nutritional status as the key modulator of antioxidant responses induced by high environmental ammonia and salinity stress in European sea bass (Dicentrarchus labrax). PloS one 2015; 10:e0135091.

[12] El - Saidy DM, Gaber M. Effect of dietary protein levels and feeding rates on growth performance, production traits and body composition of Nile tilapia, Oreochromis niloticus (L.) cultured in concrete tanks. Aquaculture research 2005; $36: 163-171$

[13] El-Zaeem SY, Ahmed MMM, Salama M, El-Maremie H. Production of salinity tolerant Nile tilapia, Oreochromis niloticus through traditional and modern breeding methods: II. Application of genetically modified breeding by introducing foreign DNA into fish gonads. African Journal of Biotechnology 2011; 10:684-695.

[14] Brett J, Groves T. 6 Physiological Energetics. Fish physiology $1979 ; 8: 279-352$.

[15] Wootton RJ. Introduction. Ecology of teleost fishes: Springer; 1990. p. 1-14.

[16] Barton BA, Iwama GK. Physiological changes in fish from stress in aquaculture with emphasis on the response and effects of corticosteroids. Annual Review of Fish Diseases 1991; 1:3-26. 
[17] Yada T, Uchida K, Kajimura S, Azuma T, Hirano T, Grau E. Immunomodulatory effects of prolactin and growth hormone in the tilapia, Oreochromis mossambicus. Journal of endocrinology 2002; 173:483-492.

[18] Ninh NH, Thoa NP, Knibb W, Nguyen NH. Selection for enhanced growth performance of Nile tilapia (Oreochromis niloticus) in brackish water (15-20ppt) in Vietnam. Aquaculture 2014; 428:1-6.

[19] de Oca GAR-M, Román-Reyes JC, Alaniz-Gonzalez A, Omar C, Serna-Delval GM-C, Rodríguez-González H. Effect of salinity on three tilapia (Oreochromis sp.) strains: hatching rate, length and yolk sac size. Int J Aqu Sci 2015; 6:96-106.

[20] Moorman BP, Lerner DT, Grau EG, Seale AP. The effects of acute salinity challenges on osmoregulation in Mozambique tilapia reared in a tidally changing salinity. Journal of Experimental Biology 2015; 218:731-739.

[21] Tran-Ngoc KT, Schrama JW, Le MT, Nguyen TH, Roem AJ, Verreth JA. Salinity and diet composition affect digestibility and intestinal morphology in Nile tilapia (Oreochromis niloticus). Aquaculture 2016.

[22] Boeuf G, Payan P. How should salinity influence fish growth? Comparative Biochemistry and Physiology Part C: Toxicology \& Pharmacology 2001; 130:411-423.

[23] Enayat Gholampoor T, Imanpoor M, Shabanpoor B, Hosseini S. The Study of Growth Performance, Body Composition and Some Blood Parameters of Rutilus frisii kutum (Kamenskii, 1901) Fingerlings at Different Salinities. Journal of Agricultural Science and Technology 2011; 13:869-876.

[24] Imsland AK, Gústavsson A, Gunnarsson S, Foss A, Árnason J, Arnarson I, et al. Effects of reduced salinities on growth, feed conversion efficiency and blood physiology of juvenile Atlantic halibut (Hippoglossus hippoglossus L.). Aquaculture 2008; 274:254-259.

[25] Usha R. EFFECT OF SALINITY CHANGES ON HAEMATOLOGICAL PARAMETERS OF THE TIGER SHARK PANGASIUS HYPOPHTHALMUS. Journal of Ecobiology 2011; 29:283.

[26] Fazio F, Marafioti S, Arfuso F, Piccione G, Faggio C. Influence of different salinity on haematological and biochemical parameters of the widely cultured mullet, Mugil cephalus. Marine and Freshwater Behaviour and Physiology 2013; 46:211-218.

[27] Soltanian S, Vazirzadeh A, Fallahi R. Effects of sudden salinity changes on short-term hematological and biochemical responses in Mudskipper Periophthalmus waltoni Koumans 1941 (Gobiidae: Perciformes). Iranian Journal of Ichthyology 2016; 3:31-42.

[28] Alwan S, Hadi A, Shokr A. Alterations in hematological parameters of fresh water fish, Tilapia zillii, exposed to aluminum. J Sci Its Appl 2009; 3:12-19.

[29] Gabriel U, Anyanwu P, Anyanwu A, Akinrotimi A. Effect of freshwater challenge on the blood characteristics of Sarotherodon melanotheron. Agricultural Journal 2007; 2:388391.

[30] Akinrotimi O, Agokei E, Aranyo A. Changes in blood parameters of Tilapia guineensis exposed to different salinity levels. Journal of Environmental Engineering and Technology 2012; 1:4-12.
[31] Svobodová Z, Flajšhans M, Kolářová J, Modrá H, Svoboda M, Vajcová V. Leukocyte profiles of diploid and triploid tench, Tinca tinca L. Aquaculture 2001;198:159-168.

[32] Sahafi HH, Masaeli S, Alizadeh M, Negarestan H, Naji T. A study on growth parameters, blood factors and proximate composition of rainbow trout (Oncorhynchus mykiss) cultured in underground brackish and freshwater. Iranian Journal of Fisheries Sciences 2013;12:836-842, IV.

[33] Amin FB. EFFECTS OF SALINITY ON PHYSIOLOGICAL AND BEHAVIORAL STRESS RESPONSES IN SILVER BARB (Barbonymus gonionotus). PhD Thesis Bangladesh Agricultural University, Mymensingh.; 2014.

[34] Semple JW, Italiano JE, Freedman J. Platelets and the immune continuum. Nature Reviews Immunology 2011;11:264-274.

[35] Stosik M, Deptula W, Travnicek M. Studies on the number and ingesting ability of thrombocytes in sick carps (Cyprinus carpio L.). VETERINARNI MEDICINA-PRAHA2001;46:12-16.

[36] Karadag H, Firat Ö, Firat Ö. Use of oxidative stress biomarkers in Cyprinus carpio L. for the evaluation of water pollution in Ataturk Dam Lake (Adiyaman, Turkey). Bulletin of environmental contamination and toxicology 2014;92:289293.

[37] Wang F, Yang H, Gao F, Liu G. Effects of acute temperature or salinity stress on the immune response in sea cucumber, Apostichopus japonicus. Comparative Biochemistry and Physiology Part A: Molecular \& Integrative Physiology 2008;151:491-498.

[38] Boya P, de la Peña A, Beloqui O, Larrea E, Conchillo M, Castelruiz Y, et al. Antioxidant status and glutathione metabolism in peripheral blood mononuclear cells from patients with chronic hepatitis C. Journal of hepatology 1999;31:808-814.

[39] Mazeaud MM, Mazeaud F, Donaldson EM. Primary and secondary effects of stress in fish: some new data with a general review. Transactions of the American Fisheries Society 1977;106:201-212.

[40] Karsi A, Yildiz HY. Secondary stress response of nile tilapia, Oreochromis niloticus, after direct transfer to different salinities. Tarim Bilimleri Dergisi 2005;11:139-141.

[41] Benli A, Yildiz HY. Alteration of renal tissue in Nile tilapia, Oreochromis niloticus, after transfer to saline water. 2004.

[42] Semra K, Karul A, Yildirim Ş, Gamsiz K. Effects of salinity on growth and metabolism in blue tilapia (Oreochromis aureus). African Journal of Biotechnology 2013;12.

[43] Vijayan M, Mommsen T, Glémet H, Moon T. Metabolic effects of cortisol treatment in a marine teleost, the sea raven. Journal of Experimental Biology 1996;199:1509-1514.

[44] Kavya K, Jadesh M, Kulkarni R. Hematology and serum biochemical changes in response to change in saline concentration in fresh water fish Notopterus notopterus. World Scientific News 2016;32:49.

[45] Sangiao-Alvarellos S, Laiz-Carrión R, Guzmán JM, del Río MPM, Miguez JM, Mancera JM, et al. Acclimation of S. aurata to various salinities alters energy metabolism of osmoregulatory and nonosmoregulatory organs. American Journal of Physiology-Regulatory, Integrative and Comparative Physiology 2003;285:R897-R907. 
[46] Sangiao-Alvarellos S, Arjona FJ, del Río MPM, Míguez JM , Mancera JM, Soengas JL. Time course of osmoregulatory and metabolic changes during osmotic acclimation in Sparus auratus. Journal of Experimental Biology 2005;208:42914304.

[47] Yılmaz S, Ergün S. Effects of garlic and ginger oils on hematological and biochemical variables of sea bass Dicentrarchus labrax. Journal of aquatic animal health 2012;24:219-224.

[48] Kelly S, Woo N. The response of sea bream following abrupt hyposmotic exposure. Journal of fish biology 1999;55:732750.

[49] Martinez-Alvarez R ,Hidalgo M, Domezain A, Morales A, García-Gallego M, Sanz A. Physiological changes of sturgeon Acipenser naccarii caused by increasing environmental salinity. Journal of experimental biology 2002;205:3699-3706.

[50] Harris J, Bird DJ. Modulation of the fish immune system by hormones. Veterinary immunology and immunopathology 2000;77:163-176.
[51] Cataldi E, Di Marco P, Mandich A, Cataudella S. Serum parameters of Adriatic sturgeon Acipenser naccarii (Pisces: Acipenseriformes): effects of temperature and stress. Comparative Biochemistry and Physiology Part A: Molecular \& Integrative Physiology 1998;121:351-354.

[52] Fiúza LS, Aragão NM, Junior R, Pinto H, Moraes MG, Rocha ÍRCB, et al. Effects of salinity on the growth, survival, haematological parameters and osmoregulation of tambaqui Colossoma macropomum juveniles. Aquaculture Research 2015;46:1-9.

[53] Khairnar SO, Tian X, Dong S, Fang Z, Solanki BV, Shanthanagouda HA. Effects of the amplitude and frequency of salinity fluctuations on antioxidant responses in juvenile tongue sole, Cynoglossus semilaevis. Spanish Journal of Agricultural Research 2016;14:0503.

[54] Louis-Cormier ES, Osterland C, Anderson PD. Evidence for a cutaneous secretory immune system in rainbow trout (Salmogairdneri). Developmental \& Comparative Immunology 1984;8:71-80. 